\title{
Toward an Integrated Use of Biological Control by Cladosporium cladosporioides H39 in Apple Scab (Venturia inaequalis) Management
}

Jürgen Köhl, Wageningen UR-Plant Research International, 6700 AB Wageningen, The Netherlands; Christian Scheer, Foundation Kompetenzzentrum Obstbau-Bodensee, 88213 Ravensburg-Bavendorf, Germany; Imre J. Holb, University of Debrecen, Centre for Agricultural Sciences and Engineering, Faculty of Agronomy, H-4015 Debrecen, Hungary, and Plant Protection Institute, Hungarian Academy of Sciences, 1525 Budapest, Hungary; Sylwester Masny, Research Institute of Horticulture, Konstytucji 3 Maja 1/3, 96-100 Skierniewice, Poland; and Wilma Molhoek, Wageningen UR-Plant Research International, The Netherlands.

\begin{abstract}
Köhl, J., Scheer, C., Holb, I. J., Masny, S., and Molhoek, W. M. L. 2015. Toward an integrated use of biological control by Cladosporium cladosporioides H39 in apple scab (Venturia inaequalis) management. Plant Dis. 99:535-543.

Apple scab, caused by Venturia inaequalis, is the most important disease in apple production, reducing yield and quality of fruit. Control of apple scab in commercial orchards currently depends on multiple applications of fungicides. The potential of the antagonistic isolate Cladosporium cladosporioides $\mathrm{H} 39$, originating from a sporulating colony of $V$. inaequalis, to control apple scab development was tested in eight trials during 2 years in orchards in Eperjeske (Hungary), Dabrowice (Poland), and Bavendorf (Germany) planted with different cultivars. Treatments were conducted as calendar sprays or after infection periods. Additional trials in an orchard in Randwijk (The Netherlands) focused on the effect of timing of antagonist application before or after infection periods. The overall results of the field trials consistently showed-for the first time- - that

stand-alone applications of the antagonist $C$. cladosporioides $\mathrm{H} 39$ can reduce apple scab in leaves and fruit. This was demonstrated in an organic growing system as well as in conventional orchards by spray schedules applied during the primary or the summer season. In both systems, the same control levels could be reached as with common fungicide schedules. Efficacies reached 42 to $98 \%$ on leaf scab incidence and 41 to $94 \%$ on fruit scab. The antagonist was also effective if applied one or even several days (equivalent to approximately 300 to 2,000 degree $h$ ) after infection events in several field trials and a trial conducted in Randwijk with single-spray applications at different intervals before or after infection events. Better understanding of the biology of the antagonist will help to further exploit its use in apple scab control.
\end{abstract}

Apple scab, caused by Venturia inaequalis (Cooke) G. Winter, is the most important disease in apple production worldwide, reducing yield and quality of fruit $(23,24)$. V. inaequalis overwinters mainly in fallen leaves but survival of conidia on twigs has also been reported (18). The saprophytical colonization of leaf litter leads to the formation of pseudothecia in which ascospores are produced. Such ascospores are released during the primary season in spring and may infect young apple leaves and young fruit. After this initiation of scab epidemics by primary ascospores, the further multicyclic development of the epidemic depends on the multiple development of the secondary conidia produced on leaves; this means that leaves and fruit can be infected throughout the whole growing season, although ontogenic resistance reduces the number of infections.

The development of preventive measures to limit the damage by apple scab focuses on the reduction of primary inoculum during overwintering in leaf litter. Removal or shredding of fallen leaves $(13,28)$ or the application of antagonists $(1,6,7)$ has been investigated. Mechanical measures can be part of a disease management strategy in commercial orchards, especially in organic farming (17). Despite the tremendous amount of research and number of publications on biological control of plant pathogens, biological control options for apple scab control are currently not available for use in practice (7). Another option is the use of resistant cultivars. However, limited acceptance by consumers as well as the breakdown of the major scab resistance gene $V f$ by $V$. inaequalis populations (14) limit the use of resistant cultivars.

Control of apple scab in commercial orchards currently depends on multiple applications of fungicides (25). Spray schedules with alternating use of active ingredients from several fungicidal groups are

Corresponding author: J. Köhl, E-mail: jurgen.kohl@wur.nl

Accepted for publication 6 October 2014.

http://dx.doi.org/10.1094/PDIS-08-14-0836-RE

(C) 2015 The American Phytopathological Society common during the primary season as well as the summer season. Several weather-based decision support systems are available for growers to support their decisions on the timing of specific fungicide applications. Timing of applications during the primary season, guided by information on ascospore discharges, is critical to prevent the build up of scab epidemics because abundant amounts of young leaf and fruit tissue, highly susceptible to $V$. inaequalis infections, are present in spring. Often, failures in scab control during spring cannot be repaired by fungicide measures later in the season. Fungicide applications during the summer season aim at the protection of newly formed susceptible young leaf tissue to prevent further build up of epidemics. Fungicides are also sprayed to prevent late infections on old leaves, often leading to latent infections, to lower the primary inoculum load for the following season (22). Summer applications of fungicides also reduce the late infection of apple fruit which may result in scab lesions on stored fruit. $V$. inaequalis populations developed resistance to an increasing number of fungicides in major apple-growing areas during recent years $(2,10)$. Furthermore, governmental regulations (e.g., in the European Union) restrict the use of fungicides (9). The increasing demand for fruit without or with low pesticide residues is another reason why alternatives for synthetic fungicides are needed.

Biological control of apple scab has been investigated for over 50 years (6), with most of the research focusing on overwintering $V$. inaequalis. The antagonists Athelia bombacina (15) and Microphaeropsis sp. (8). showed a high potential to reduce ascospore formation in leaf litter. Field application of Microphaeropsis sp. resulted in an ascospore reduction of 75 to $80 \%$. Reports on biological control of apple scab in the canopy are rare $(3,5,11,12)$. Recently, the antagonistic isolate Cladosporium cladosporioides $\mathrm{H} 39$ has been isolated from a sporulating colony of $V$. inaequalis on an apple leaf collected from a Dutch orchard $(20,21)$. This isolate reduced the production of $V$. inaequalis conidia on apple seedlings when applied 1 to 3 days after inoculation with the pathogen.

The objective of our study was to assess the effect of applications of $C$. cladosporioides $\mathrm{H} 39$ on apple scab development under orchard 
conditions and to test the hypothesis that timing of antagonist applications may affect treatment efficacy. Treatments were conducted as calendar sprays during the primary season and the summer season. Another strategy was to apply the antagonist after predicted infection periods similar to the situation created during the screening bioassays (21). Additional experiments focused on the effect of timing of antagonist application before or after infection periods and its compatibility with agrochemicals commonly used in apple production.

\section{Material and Methods}

Orchards and experimental design. Eight trials were carried out in orchards at three locations to assess the effect of applications of $C$. cladosporioides $\mathrm{H} 39$ on apple scab development. The effect of timing of single applications of $C$. cladosporioides $\mathrm{H} 39$ on sporulation of $V$. inaequalis was tested in additional trials in Randwijk. All trials were conducted in a fully randomized block design. Orchard characteristics and experimental designs are shown in Tables 1 and 2. During the trials, meteorological data were collected using a METOS agrometeorological station (Pessl Instrument GmbH, Weiz, Austria) in Eperjeske and Dabrowice, a Campbell CR-800 station (Campbell Scientific, Logan, UT) in Bavendorf, and a Mety station (Bodata, Dordrecht, The Netherlands) in Randwijk. Risks of infection periods by $V$. inaequalis were forecasted using RIMpro (Bio Fruit Advies, Zoelmond, The Netherlands) in Eperjeske, Dabrowice, and Randwijk and SCHORF (version 5.07; Farm Software GmbH, Bermatingen, Germany) in Bavendorf.

Treatments and assessments. Conidia of $C$. cladosporioides strain H39 (20) were produced on a cereal-based solid growth medium. Conidia were pilot formulated using a detergent to achieve optimum applicability and spread on the target. In an additional treatment in Eperjeske, Hungary, nonformulated spores were applied. Suspensions applied at the different locations contained $2 \times 10^{6}$ conidia/ml. In an additional treatment in Bavendorf in 2013, suspensions containing $6 \times 10^{6}$ conidia/ml were also applied for comparison.
The basic treatments in the trials were (i) untreated control; (ii) a reference fungicide schedule; (iii) C. cladosporioides $\mathrm{H} 39$ applications at regular intervals, usually 7 days but with extended intervals during periods of dry weather when no progress of scab epidemics was expected; (iv) C. cladosporioides $\mathrm{H} 39$ applications 1 day after predicted infection events by $V$. inaequalis on dry leaves, which was slightly modified in the trial in Eperjeske in 2013, where applications were applied 500 to 600 degree $\mathrm{h}$ after infection events on dry leaves; and (v) alternating applications of fungicides and C. cladosporioides $\mathrm{H} 39$. Treatments iii to $\mathrm{v}$ were not conducted in all trials. Fungicides used were copper oxychloride (Funguran, $500 \mathrm{~g}$ a.i./kg, applied at $1 \mathrm{~kg} / \mathrm{ha}$ ) and calcium polysulfide (lime sulfur, $290 \mathrm{~g}$ a.i./liter, applied at $1.5 \mathrm{l} / \mathrm{ha}$ ) in the organically managed orchards in Eperjeske; and dithianon (Delan, containing $700 \mathrm{~g}$ a.i. $\mathrm{kg}^{-1}$ ), applied at $0.65 \mathrm{~kg} / \mathrm{ha}$ in Dabronice and $0.25 \mathrm{~kg} / \mathrm{ha}$ in Bavendorf, or dodine (Syllit, containing $400 \mathrm{~g}$ a.i./liter) applied at 0.625 liter/ha in the other orchards. Details on application frequencies and techniques are shown in Tables 1 to 3. Disease incidence (\%) and phytotoxicity were assessed at the end of the primary or summer season (Table 2) on randomly chosen leaves and fruit. Infestation was assessed on 200 leaves and 50 fruit per plot in Eperjeske, on 200 leaves and 100 fruit in Dabrowice (where disease severity was also assessed using a sixpoint scale of evaluation from $0=$ no symptoms to $5=$ more than $75 \%$ of the area covered by scab in the case of leaves and more than $30 \%$ for fruit), and on 200 leaves and 200 fruit per plot in Bavendorf, except for the trial in 2013, where all leaves of 20 randomly chosen extension shoots per plot (ranging from 195 to 308 leaves) were assessed.

In most trials, fungicide schedules had been applied on all experimental plots before the trials started: 10 treatments with copper oxychloride or elementary sulfur in trial Eperjeske 2012; 2 treatments with copper oxychloride or dithianon in trial 1 in Dabrowice; 10 treatments with captan, copper oxychloride, difenoconazole, dithianon, pyrimethanil, thiram, or trifloxystrobin in trial 2 in Dabrowice; and 14 treatments with captan, copper oxychloride, dithianon, dodine, myclobutanil, pyraclostrobin, or trifloxystrobin in trial 2 in 2012 and

Table 1. Orchard characteristics and application techniques

\begin{tabular}{|c|c|c|c|c|c|c|c|}
\hline \multirow[b]{2}{*}{ Location } & \multirow[b]{2}{*}{$\begin{array}{l}\text { Cultivar and } \\
\text { rootstock }\end{array}$} & \multirow[b]{2}{*}{$\begin{array}{l}\text { Planting } \\
\text { year }\end{array}$} & \multicolumn{2}{|c|}{$\begin{array}{c}\text { Planting } \\
\text { distance (m) }\end{array}$} & \multirow[b]{2}{*}{$\begin{array}{c}\text { Canopy } \\
\text { height (m) }\end{array}$} & \multicolumn{2}{|c|}{ Spray applications } \\
\hline & & & $\begin{array}{c}\text { Within } \\
\text { rows }\end{array}$ & $\begin{array}{l}\text { Between } \\
\text { rows }\end{array}$ & & Equipment & $\begin{array}{l}\text { Volume } \\
\text { (liters/ha) }\end{array}$ \\
\hline $\begin{array}{l}\text { Eperjeske }\left(48^{\circ} 21^{\prime} 30^{\prime \prime} \mathrm{N}, 22^{\circ} 13^{\prime} 10^{\prime \prime} \mathrm{E}\right)^{\mathrm{z}} \\
\text { Dabrowice }\left(52^{\circ} 18^{\prime} 22^{\prime \prime} \mathrm{N}, 19^{\circ} 4^{\prime} 44^{\prime \prime} \mathrm{E}\right)\end{array}$ & Idared on M26 & 1996 & 2.0 & 5.0 & 3.2 & Handheld spray gun & 600 \\
\hline Trial 1 & Cortland on M26 & 2003 & 1.8 & 3.5 & 2.6 & Air blast sprayer & 1,300 \\
\hline Trial 2 & McIntosh on M26 & 2003 & 1.8 & 3.5 & 2.6 & Air blast sprayer & 1,300 \\
\hline Bavendorf $\left(47^{\circ} 45^{\prime} 37^{\prime \prime} \mathrm{N}, 9^{\circ} 32^{\prime} 31^{\prime \prime} \mathrm{E}\right)$ & & & & & & & \\
\hline 2012, Trials 1 and 2 & Golden Delicious on M9 & 2001 & 0.8 & 3.2 & 2.25 & Air blast sprayer & 500 \\
\hline 2013, Trials 1 and 2 & Golden Delicious on M9 & 2008 & 1.0 & 3.5 & 2.0 & Air blast sprayer & 500 \\
\hline Randwijk $\left(51^{\circ} 56^{\prime} 18^{\prime \prime} \mathrm{N}, 5^{\circ} 42^{\prime} 23^{\prime \prime} \mathrm{E}\right)$ & Jonagold on M9 & 1998 & 1.0 & 3.0 & 2.5 & Knapsack sprayer & Until run-off \\
\hline
\end{tabular}

${ }^{\mathrm{z}}$ Hungarian organic production guidelines applied.

Table 2. Experimental design of field trials

\begin{tabular}{|c|c|c|c|c|c|c|}
\hline \multirow[b]{2}{*}{ Trial } & \multicolumn{3}{|c|}{ Number of } & \multicolumn{2}{|c|}{ Period of applications } & \multirow[b]{2}{*}{ Assessment dates } \\
\hline & Treatments & Replicates & Trees per plot & Primary season & Summer season & \\
\hline Eperjeske 2012 & 6 & 5 & 7 & $\ldots$ & 8 June-7 September & 3 October \\
\hline Eperjeske 2013 & 6 & 5 & 7 & 26 March-4 June & $\ldots$ & 21 June \\
\hline Dabrowice 2013 , trial 1 & 4 & 4 & 5 & 29 April-29 May & 12 June-22 August & $\begin{array}{l}25 \text { June, } 17 \text { October (leaves); } \\
26 \text { July, } 12 \text { September (fruit) }\end{array}$ \\
\hline Dabrowice 2013, trial 2 & 5 & 4 & 5 & $\ldots$ & 14 June-22 August & 17 October (leaves), 10 September (fruit) \\
\hline Bavendorf 2012 trial 1 & 3 & 4 & 12 & 29 March-16 May & $\ldots$ & 10 May and 23 May \\
\hline Bavendorf 2012 trial 2 & 3 & 4 & 12 & $\cdots$ & 11 June-18 September & $\begin{array}{l}6 \text { June, } 11 \text { July (leaves); } \\
8 \text { August, } 21 \text { September (fruit) }\end{array}$ \\
\hline Bavendorf 2013 trial 1 & 4 & 4 & 12 & 21 April-27 May & $\ldots$ & 23 May, 5 June \\
\hline Bavendorf 2013 trial 2 & 4 & 4 & 12 & $\cdots$ & 11 June-17 September & $\begin{array}{l}6 \text { June, } 18 \text { July (leaves); } \\
26 \text { September (fruit) }\end{array}$ \\
\hline
\end{tabular}


trial 2 in 2013 in Bavendorf. These schedules were similar to common practice in commercial orchards in the growing areas, and application dates were chosen depending on predicted ascospore flights and infection periods.

Three additional small-scale trials were carried out in an orchard in Randwijk, The Netherlands, with single-spray applications of $C$. cladosporioides H39 on 'Jonagold'. These trials contained five treatments in a completely randomized block design with six blocks (replicates). Each plot consisted of one tree. The youngest justunfolded leaves of 5 shoots/tree were labeled. Spray applications were timed so that the antagonist was applied approximately $350 \mathrm{de}-$ gree h before a predicted infection event. In the other treatments, $C$. cladosporioides H39 was applied approximately 1,000, 2,000, or 3,000 degree $\mathrm{h}$ after the predicted infection event. Untreated trees served as control. The labeled leaf, not yet unfolded at the beginning of the trial, and the next two elder leaves of each of the five labeled shoots per plot were sampled separately 20 days after the predicted infection event. The five leaves of similar age per plot were pooled and shaken in $30 \mathrm{ml}$ of water containing $0.01 \%$ (vol/vol) Tween 80 , and the number of $V$. inaequalis conidia per milliliter was

Table 3. Application dates of sprays of Cladosporium cladosporioides $\mathrm{H} 39$ and fungicides

\begin{tabular}{|c|c|c|c|c|c|c|c|c|c|c|c|c|c|c|c|c|}
\hline \multirow{2}{*}{$\frac{\text { Trial }}{\text { Eperjeske } 2012}$} & \multirow{2}{*}{$\begin{array}{c}\text { Sprays } \\
\text { Copper oxychloride }\end{array}$} & \multicolumn{15}{|c|}{ Applications dates } \\
\hline & & 8 Jun & 15 Jun & 24 Jun & $4 \mathrm{Jul}$ & $14 \mathrm{Jul}$ & $28 \mathrm{Jul}$ & 13 Aug & 26 Aug & 7 Sep & $\ldots$ & $\ldots$ & $\ldots$ & $\ldots$ & $\ldots$ & $\ldots$ \\
\hline & $\mathrm{H} 39$, interval & 8 Jun & 15 Jun & 22 Jun & 29 Jun & $5 \mathrm{Jul}$ & $13 \mathrm{Jul}$ & $20 \mathrm{Jul}$ & $27 \mathrm{Jul}$ & 2 Aug & 9 Aug & 16 Aug & 23 Aug & 30 Aug & $6 \mathrm{Sep}$ & $\ldots$ \\
\hline & $\mathrm{H} 39$, after infection & 9 Jun & 14 Jun & 20 Jun & 27 Jun & $4 \mathrm{Jul}$ & $11 \mathrm{Jul}$ & $22 \mathrm{Jul}$ & 2 Aug & 14 Aug & 18 Aug & 26 Aug & $5 \mathrm{Sep}$ & $\ldots$ & $\ldots$ & $\ldots$ \\
\hline \multirow[t]{4}{*}{ Eperjeske 2013} & Copper oxychloride & $26 \mathrm{Mar}$ & $6 \mathrm{Apr}$ & 15 Apr & $21 \mathrm{Apr}$ & $30 \mathrm{Apr}$ & 4 May & 9 May & 16 May & 24 May & 1 Jun & $\ldots$ & $\ldots$ & $\ldots$ & $\ldots$ & $\ldots$ \\
\hline & H39, interval & $26 \mathrm{Mar}$ & $2 \mathrm{Apr}$ & 9 Apr & $16 \mathrm{Apr}$ & $23 \mathrm{Apr}$ & $30 \mathrm{Apr}$ & 7 May & 14 May & 21 May & 28 May & 4 Jun & $\ldots$ & $\ldots$ & $\ldots$ & $\ldots$ \\
\hline & $\mathrm{H} 39$, after infection & $28 \mathrm{Mar}$ & $9 \mathrm{Apr}$ & $17 \mathrm{Apr}$ & $24 \mathrm{Apr}$ & $30 \mathrm{Apr}$ & 7 May & 12 May & 19 May & 25 May & 4 Jun & $\ldots$ & $\ldots$ & $\ldots$ & $\ldots$ & $\ldots$ \\
\hline & Lime sulfur & 27 Mar & $8 \mathrm{Apr}$ & $17 \mathrm{Apr}$ & $23 \mathrm{Apr}$ & 29 Apr & 6 May & 11 May & 18 May & 24 May & 3 Jun & $\ldots$ & $\ldots$ & $\ldots$ & $\ldots$ & $\ldots$ \\
\hline \multirow[t]{2}{*}{ Dabrowice 2013 , trial 1} & Dithianon & $29 \mathrm{Apr}$ & 6 May & 13 May & 21 May & 29 May & 5 Jun & 12 Jun & 24 Jun & $15 \mathrm{Jul}$ & $\ldots$ & $\ldots$ & $\ldots$ & $\ldots$ & $\ldots$ & $\ldots$ \\
\hline & $\mathrm{H} 39$, interval & $29 \mathrm{Apr}$ & 6 May & 13 May & 21 May & 29 May & 12 Jun & 19 Jun & 24 Jun & $2 \mathrm{Jul}$ & $12 \mathrm{Jul}$ & $24 \mathrm{Jul}$ & 1 Aug & 12 Aug & 22 Aug & $\ldots$ \\
\hline \multirow[t]{3}{*}{ Dabrowice 2013 , trial 2} & Dithianon & 14 Jun & 24 Jun & $15 \mathrm{Jul}$ & $23 \mathrm{Aug}$ & $\ldots$ & $\ldots$ & $\ldots$ & $\ldots$ & $\ldots$ & $\ldots$ & $\ldots$ & $\ldots$ & $\ldots$ & $\ldots$ & $\ldots$ \\
\hline & H39, interval & 14 Jun & 19 Jun & 24 Jun & $2 \mathrm{Jul}$ & $12 \mathrm{Jul}$ & $24 \mathrm{Jul}$ & 1 Aug & 12 Aug & 22 Aug & $\ldots$ & $\ldots$ & $\ldots$ & $\ldots$ & $\ldots$ & $\ldots$ \\
\hline & H39, after infection & 14 Jun & 24 Jun & $15 \mathrm{Jul}$ & $23 \mathrm{Aug}$ & $\ldots$ & $\ldots$ & $\ldots$ & $\ldots$ & $\ldots$ & $\ldots$ & $\ldots$ & $\ldots$ & $\ldots$ & $\ldots$ & $\ldots$ \\
\hline \multirow[t]{2}{*}{ Bavendorf 2012 trial 1} & Dithianon & $29 \mathrm{Mar}$ & $2 \mathrm{Apr}$ & $10 \mathrm{Apr}$ & 17 Apr & $25 \mathrm{Apr}$ & 2 May & 9 May & 16 May & $\ldots$ & $\ldots$ & $\ldots$ & $\ldots$ & $\ldots$ & $\ldots$ & $\ldots$ \\
\hline & $\mathrm{H} 39$, interval & $29 \mathrm{Mar}$ & $2 \mathrm{Apr}$ & $10 \mathrm{Apr}$ & $17 \mathrm{Apr}$ & $25 \mathrm{Apr}$ & 2 May & 9 May & 16 May & $\ldots$ & $\ldots$ & $\ldots$ & $\ldots$ & $\ldots$ & $\ldots$ & $\ldots$ \\
\hline \multirow[t]{2}{*}{ Bavendorf 2012 trial 2} & Dithianon & 11 Jun & 18 Jun & 26 Jun & $3 \mathrm{Jul}$ & $10 \mathrm{Jul}$ & $17 \mathrm{Jul}$ & $24 \mathrm{Jul}$ & $31 \mathrm{Jul}$ & 7 Aug & 13 Aug & 21 Aug & 28 Aug & 5 Sep & $11 \mathrm{Sep}$ & $18 \mathrm{Sep}$ \\
\hline & $\mathrm{H} 39$, interval & $11 \mathrm{Jun}$ & 18 Jun & 26 Jun & $3 \mathrm{Jul}$ & $10 \mathrm{Jul}$ & $17 \mathrm{Jul}$ & $24 \mathrm{Jul}$ & $31 \mathrm{Jul}$ & 7 Aug & 13 Aug & 21 Aug & 28 Aug & 5 Sep & 11 Sep & $18 \mathrm{Sep}$ \\
\hline \multirow[t]{2}{*}{ Bavendorf 2013 trial 1} & Dodine & $21 \mathrm{Apr}$ & $29 \mathrm{Apr}$ & 4 May & 6 May & 11 May & 13 May & 21 May & 24 May & 27 May & $\ldots$ & $\ldots$ & $\ldots$ & $\ldots$ & $\ldots$ & $\ldots$ \\
\hline & $\mathrm{H} 39$, after infection & $21 \mathrm{Apr}$ & $29 \mathrm{Apr}$ & 4 May & 6 May & 11 May & 13 May & 21 May & 24 May & 27 May & $\ldots$ & $\ldots$ & $\ldots$ & $\ldots$ & $\ldots$ & $\ldots$ \\
\hline \multirow[t]{2}{*}{ Bavendorf 2013 trial 2} & Dodine & 11 Jun & 21 Jun & 26 Jun & $4 \mathrm{Jul}$ & $25 \mathrm{Jul}$ & 7 Aug & 28 Aug & 9 Sep & 17 Sep & $\ldots$ & $\ldots$ & $\ldots$ & $\ldots$ & $\ldots$ & $\ldots$ \\
\hline & H39, after infection & 11 Jun & 21 Jun & 26 Jun & $4 \mathrm{Jul}$ & $25 \mathrm{Jul}$ & 7 Aug & 28 Aug & 9 Sep & 17 Sep & $\ldots$ & $\ldots$ & $\ldots$ & $\ldots$ & $\ldots$ & $\ldots$ \\
\hline
\end{tabular}

Table 4. Agrochemicals tested for their effects on Cladosporium cladosporioides H39

\begin{tabular}{|c|c|c|c|c|}
\hline Product trade name & Active ingredient & Producer & Concentration of a.i. & Maximum rate of product tested ${ }^{\mathrm{z}}$ \\
\hline Admire & Imacloprid & Bayer Crop Science & $700 \mathrm{~g} / \mathrm{kg}$ & $0.5 \mathrm{~g} /$ liter \\
\hline Armicarb & Potassium bicarbonate & Agronaturalis & $850 \mathrm{~g} / \mathrm{kg}$ & $5.88 \mathrm{~g} / \mathrm{liter}$ \\
\hline \multirow[t]{2}{*}{ Bellis } & Pyraclostrobin & BASF & $128 \mathrm{~g} / \mathrm{kg}$ & $4 \mathrm{~g} /$ liter \\
\hline & Boscalid & & $252 \mathrm{~g} / \mathrm{kg}$ & \\
\hline Calypso & Thiacloprid & Bayer CropScience & $480 \mathrm{~g} /$ liter & $1.25 \mathrm{ml} /$ liter \\
\hline Delan WG & Dithianon & Cropcare & $700 \mathrm{~g} / \mathrm{kg}$ & $2.125 \mathrm{~g} /$ liter \\
\hline DiPel & Bacillus thuringiensis & Valent Biosciences & $450 \mathrm{~g} / \mathrm{kg}$ & $5 \mathrm{~g} /$ liter \\
\hline Exact & Triadimenol & Bayer CropScience & $50 \mathrm{~g} / \mathrm{liter}$ & $2.5 \mathrm{ml} /$ liter \\
\hline Flint & Trifloxystrobine & Bayer CropScience & $500 \mathrm{~g} / \mathrm{kg}$ & $0.5 \mathrm{~g} /$ liter \\
\hline Folicur & Tebuconazole & Bayer CropScience & $250 \mathrm{ml} / \mathrm{liter}$ & $1 \mathrm{ml} / \mathrm{liter}$ \\
\hline Funguran & Copper oxychloride & Spiess Urania & $500 \mathrm{~g} / \mathrm{kg}$ & $1.25 \mathrm{~g} / \mathrm{liter}$ \\
\hline Gazelle & Acetamiprid & Certis & $200 \mathrm{~g} / \mathrm{kg}$ & $1.25 \mathrm{~g} / \mathrm{liter}$ \\
\hline Insegar & Fenoxicarb & Syngenta & $250 \mathrm{~g} / \mathrm{kg}$ & $1.5 \mathrm{~g} /$ liter \\
\hline Kumulus & Sulfur & BASF & $800 \mathrm{~g} / \mathrm{kg}$ & $10 \mathrm{~g} / \mathrm{liter}$ \\
\hline Yates lime sulfur & Calcium polysulfides & Yates Australia & $200 \mathrm{~g} /$ liter & $50 \mathrm{ml} /$ liter \\
\hline MaxCel & 6-Benzyladenine & Valent Biosciences & $19 \mathrm{~g} /$ liter & $25 \mathrm{ml} /$ liter \\
\hline Merpan WG & Captan & Farmoz & $800 \mathrm{~g} / \mathrm{kg}$ & $6.5 \mathrm{~g} /$ liter \\
\hline Spoiler & Mineral oil & Van Wesemael & $844 \mathrm{~g} /$ liter & $30 \mathrm{ml} /$ liter \\
\hline Nimrod & Bupirimate & Farmoz & $250 \mathrm{~g} /$ liter & $2.5 \mathrm{~g} /$ liter \\
\hline Pirimor & Pirimicarb & Syngenta & $500 \mathrm{~g} / \mathrm{kg}$ & $2.5 \mathrm{~g} /$ liter \\
\hline Runner & Methoxyfenozide & Bayer CropScience & $240 \mathrm{~g} /$ liter & $2 \mathrm{ml} / \mathrm{liter}$ \\
\hline Scala & Pyrimethanil & Bayer CropScience & $400 \mathrm{~g} /$ liter & $3.75 \mathrm{ml} /$ liter \\
\hline Score & Difenoconazole & Syngenta & $100 \mathrm{~g} / \mathrm{kg}$ & $1.875 \mathrm{~g} /$ liter \\
\hline Steward & Inoxacarb & DuPont & $158 \mathrm{~g} /$ liter & $0.850 \mathrm{~g} /$ liter \\
\hline Stroby & Kresoxim-methyl & BASF & $500 \mathrm{~g} / \mathrm{kg}$ & $1 \mathrm{~g} /$ liter \\
\hline \multirow[t]{2}{*}{ Switch } & Fludioxonil & Syngenta & $250 \mathrm{~g} / \mathrm{kg}$ & $4 \mathrm{~g} /$ liter \\
\hline & Cyprodinyl & & $375 \mathrm{~g} / \mathrm{kg}$ & \\
\hline Syllit & Dodine & Campbell Chemicals & $400 \mathrm{~g} /$ liter & $6.5 \mathrm{ml} / \mathrm{liter}$ \\
\hline Teppeki & Flonicamid & Belchim & $500 \mathrm{~g} / \mathrm{kg}$ & $0.7 \mathrm{~g} / \mathrm{liter}$ \\
\hline Topaz & Penconazole & Syngenta & $100 \mathrm{~g} / \mathrm{kg}$ & $1.25 \mathrm{ml} /$ liter \\
\hline Tracer & Spinozad & Dow Agro Science & $442 \mathrm{~g} / \mathrm{kg}$ & $0.75 \mathrm{ml} /$ liter \\
\hline Vertimec & Abamectine & Syngenta & $18 \mathrm{~g} /$ liter & $3.75 \mathrm{ml} /$ liter \\
\hline
\end{tabular}

${ }^{\mathrm{z}}$ Based on a spray volume of 1,000 liters/ha for mineral oil and Armicarb and 200 liters/ha for all other agrochemicals. 
counted using a hemocytometer. The leaf area of the sets of five leaves was measured (LI3100 area meter, LI-COR Nebraska) and the number of $V$. inaequalis conidia per square centimeter was calculated.

Compatibility of $C$. cladosporioides $\mathrm{H} 39$ with plant protection products. The effects of agrochemicals used in apple production in integrated pest management and organic systems (Table 4) on conidial germination and on mycelial growth of C. cladosporioides $\mathrm{H} 39$ were assessed in vitro.

Conidial germination. C. cladosporioides $\mathrm{H} 39$ was grown in petri dishes on potato dextrose agar (PDA; $39 \mathrm{~g} /$ liter; Oxoid) for 9 days at $20^{\circ} \mathrm{C}$ in the dark. To obtain conidial suspensions, cultures were flooded with sterile tap water containing $0.01 \%$ Tween 80 . After gently rubbing with a rubber spatula, the resulting suspension was filtered through sterile $200-\mu \mathrm{m}$ nylon gauze. Concentrations of the conidial suspensions were determined by using a hemacytometer and adjusted with sterile tap water containing $0.01 \%$ Tween 80 to $5 \times$ $10^{5}$ conidia/ml. Flasks containing the conidial suspensions were kept in ice water and suspensions were sprayed within $1 \mathrm{~h}$ on malt agar (1/10 strength) in petri dishes (60 $\mathrm{mm}$ in diameter) amended with various agrochemicals at different concentrations (Table 4; Figs. 1-3). Two petri dishes $(60 \mathrm{~mm}$ in diameter) were used for each combination of agrochemical and concentration. Petri dishes were incubated for $24 \mathrm{~h}$ in the dark at $20^{\circ} \mathrm{C}$. Thereafter, fungal growth in the dishes was stopped by adding $1 \mathrm{ml}$ of household ammonia (4.8\% [wt/wt] $\left.\mathrm{NH}_{4} \mathrm{OH}\right)$ onto a filter paper $(40 \mathrm{~mm})$ placed in the lid of the petri dish. Germination was assessed from 50 arbitrarily chosen conidia of C. cladosporioides H39. Conidia with germ tubes longer than half of the conidial length were considered as germinated. The experiment was conducted twice.

Mycelial growth. C. cladosporioides H39 was incubated for 14 days on malt agar (1/10 strength; malt extract [Oxoid] at $1 \mathrm{~g} / \mathrm{liter})$.
A
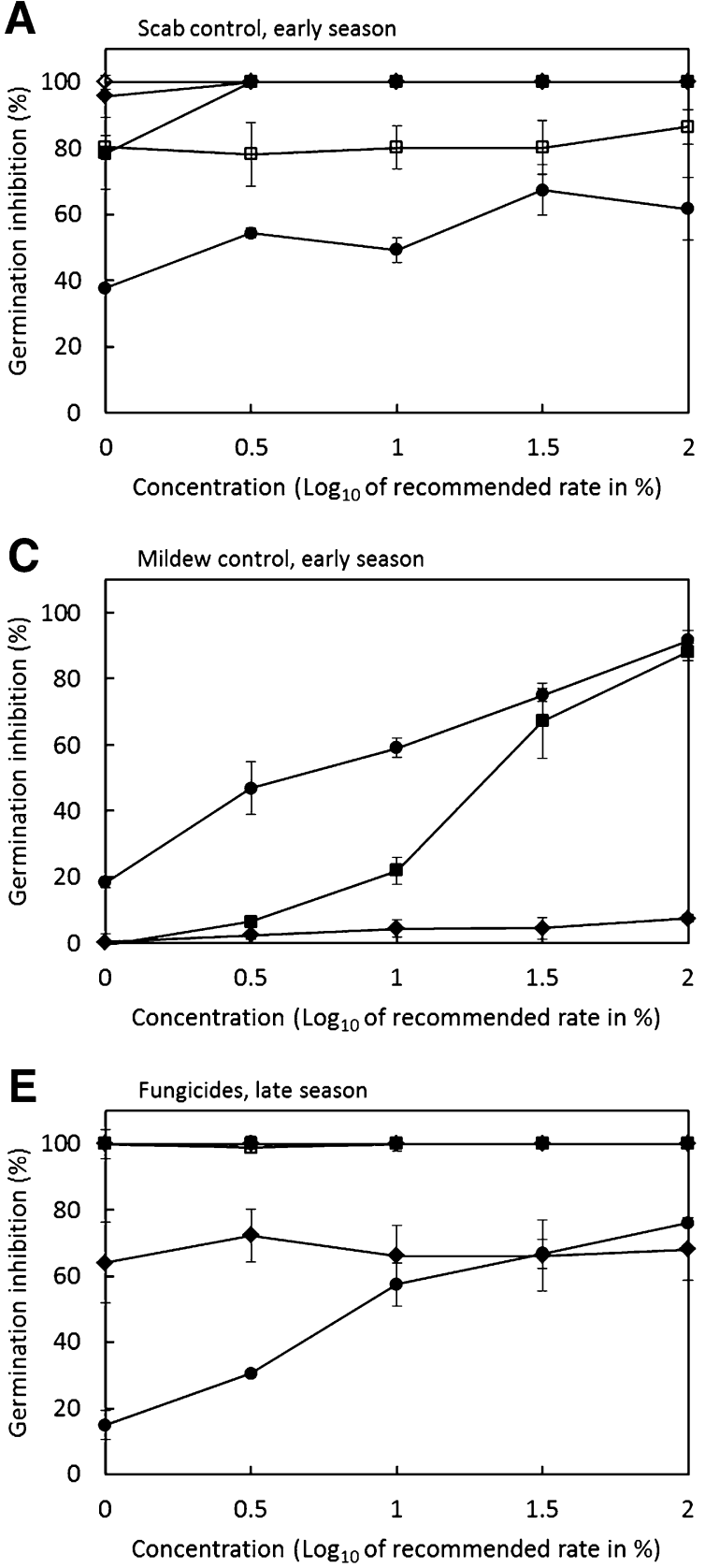
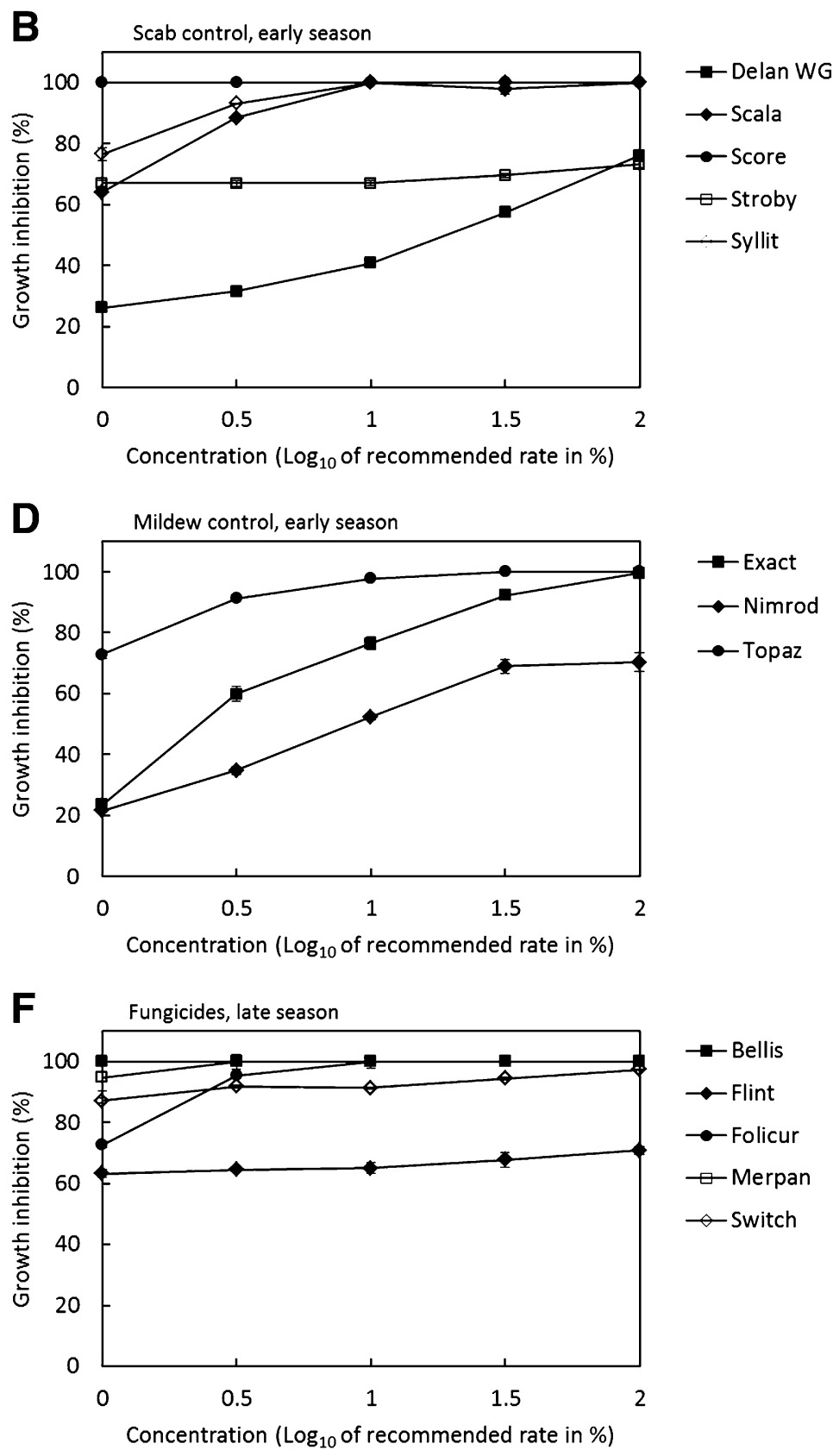

Fig. 1. Effect of fungicides used in apple orchards for $\mathbf{A}$ and $\mathbf{B}$, scab control during the early season; $\mathbf{C}$ and $\mathbf{D}$, powdery mildew control during the summer season; and $\mathbf{E}$ and $\mathbf{F}$, scab control during the summer season on $\mathbf{A}, \mathbf{C}$, and $\mathbf{E}$, conidial germination and $\mathrm{B}, \mathrm{D}$, and $\mathrm{F}$, mycelial growth of Cladosporium cladosporioides $\mathrm{H} 39$ on agar in petri dishes. Bars indicate standard error of the mean. 
Agar disks (4 mm in diameter) from the edges of colonies were transferred to malt agar amended with various agrochemicals at different concentrations (Table 4; Figs. 1-3). Two petri dishes (90 $\mathrm{mm}$ in diameter) were used for each combination of agrochemical and concentration. Petri dishes were incubated for 10 days in the dark at $20^{\circ} \mathrm{C}$. Thereafter, the diameter of each C. cladosporioides $\mathrm{H} 39$ colony was measured twice on rectangular positions and the mean daily growth rate of the colony was calculated. The experiment was conducted twice.

Statistics. Data from each of the eight orchard trials in Eperjeske, Dabrowice, and Bavendorf were analyzed separately per assessment date by analysis of variance (ANOVA) followed by Fisher's protected least significant difference (LSD) tests for multiple comparisons of the means of the different treatments (GENSTAT, 16th ed.; one- and two-way ANOVA). The numbers of $V$. inaequalis conidia produced on leaves in the trials in Randwijk were $\log _{10}$ transformed before analysis to obtain normal distributions and the effects of antagonist treatments versus untreated control were tested by one-sided LSD tests. Data on the efficacy of the agrochemicals compared with control treatments without agrochemicals are presented as overall mean and standard error of the mean if no differences were found between the repeated experiments.

\section{Results}

Spray schedule trials in Eperjeske, Dabrowice, and Bavendorf. Apple scab epidemics occurred in the eight field trials carried out in Eperjeske, Dabrowice, and Bavendorf. Environmental conditions were more conducive in Eperjeske in 2012 and in Bavendorf in 2013.

In the trials in Eperjeske during the summer season 2012, applications of nonformulated or formulated conidia of $C$. cladosporioides $\mathrm{H} 39$ at weekly intervals reduced scab on leaves and fruit $(P<$ $0.001)$ as effectively as the copper-based spray schedule commonly used in organic farming (Table 5, trial 2012). Applications of the formulation without conidia of $C$. cladosporioides $\mathrm{H} 39$ did not reduce
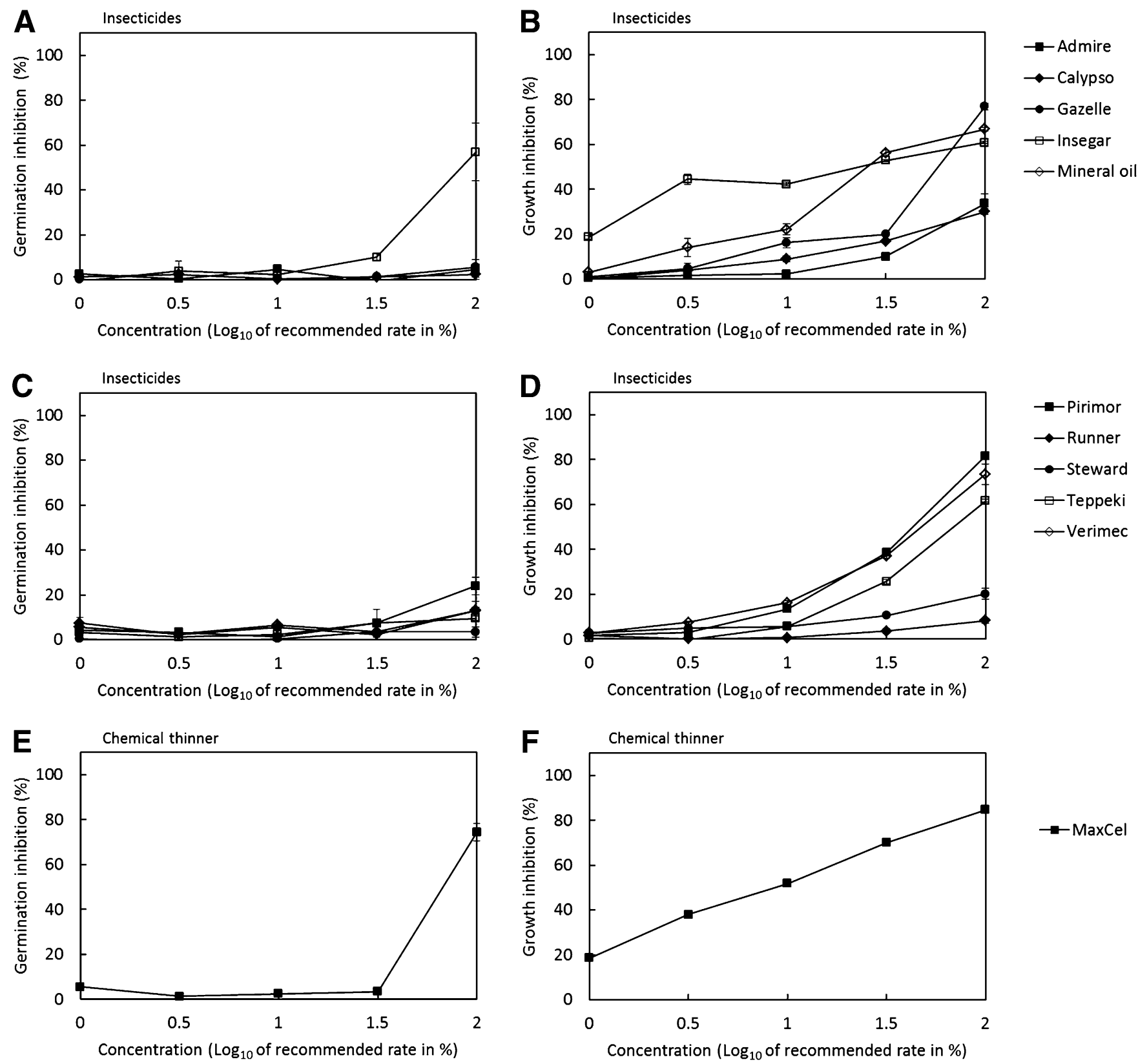

Fig. 2. Effect of $\mathbf{A}-\mathbf{D}$, insecticides used in apple orchards and $\mathbf{E}$, and $\mathbf{F}$, a chemical thinner on $\mathbf{A}, \mathbf{C}$, and $\mathbf{E}$, conidial germination and $\mathbf{B}, \mathbf{D}$, and $\mathbf{F}$, mycelial growth of Cladosporium cladosporioides $\mathrm{H} 39$ on agar in petri dishes. Bars indicate standard error of the mean. 

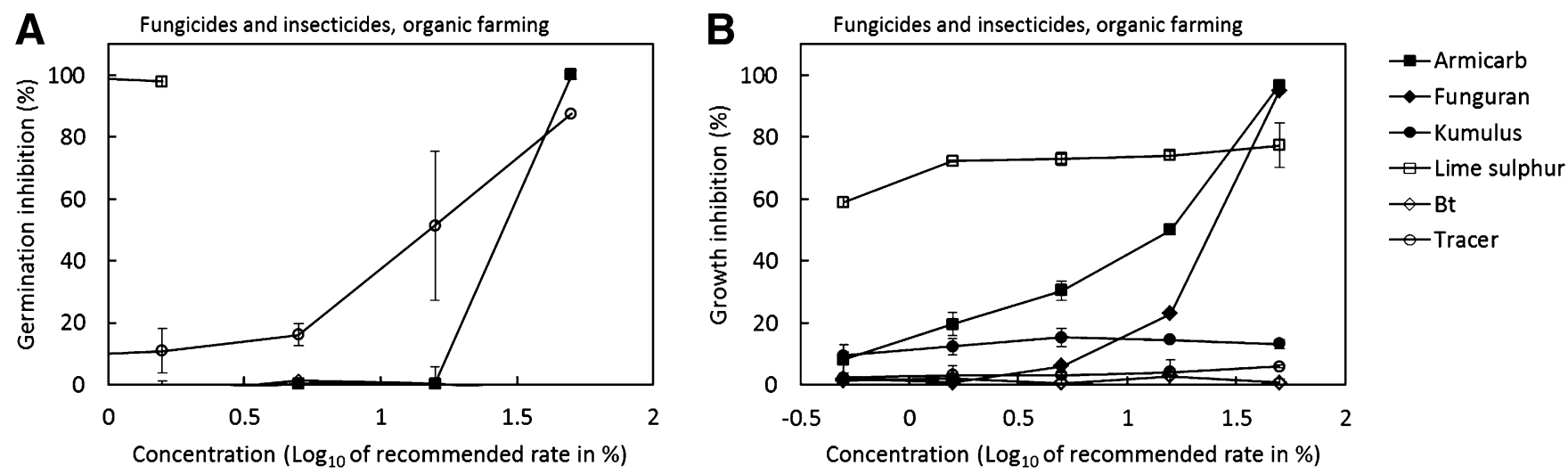

Fig. 3. Effect of fungicides and insecticides used in organic apple orchards on $\mathbf{A}$, conidial germination and $\mathbf{B}$, mycelial growth of Cladosporium cladosporioides $\mathrm{H} 39$ on agar in petri dishes. Effect on conidial germination was tested only for Armicarb and Tracer, and for lime sulfur at the lowest concentration. Bars indicate standard error of the mean.

Table 5. Effects of different application strategies of Cladosporium cladosporioides H39 on apple scab incidence on leaves and fruit in comparison with a copper spray schedulew

\begin{tabular}{|c|c|c|c|}
\hline \multirow[b]{2}{*}{ Treatment $^{\mathrm{x}}$} & \multirow[b]{2}{*}{ Number of applications } & \multicolumn{2}{|c|}{ Scab incidence $(\%)$ on } \\
\hline & & Leaves & Fruit \\
\hline \multicolumn{4}{|l|}{ Trial $2012^{\mathrm{y}}$} \\
\hline Untreated control & - & $70.1 \mathrm{a}$ & $45.2 \mathrm{a}$ \\
\hline Copper oxychloride & 9 & $35.8 \mathrm{c}$ & $20.2 \mathrm{~d}$ \\
\hline $\mathrm{H} 39$, nonformulated conidia, interval & 14 & $34.8 \mathrm{c}$ & $24.3 \mathrm{~cd}$ \\
\hline H39, interval & 14 & $39.7 \mathrm{c}$ & $26.0 \mathrm{~cd}$ \\
\hline $\mathrm{H} 39$, after infection & 12 & $52.6 \mathrm{~b}$ & $30.5 \mathrm{bc}$ \\
\hline Pilot-formulation, interval & 14 & $64.2 \mathrm{a}$ & $37.4 \mathrm{ab}$ \\
\hline \multicolumn{4}{|l|}{ Trial $2013^{z}$} \\
\hline Untreated control & - & $46.7 \mathrm{a}$ & $32.5 \mathrm{a}$ \\
\hline Copper oxychloride & 10 & $20.7 \mathrm{c}$ & $15.2 \mathrm{c}$ \\
\hline $\mathrm{H} 39$, interval & 11 & $22.3 \mathrm{c}$ & $17.6 \mathrm{c}$ \\
\hline $\mathrm{H} 39$, after infection & 10 & $30.5 \mathrm{~b}$ & $24.8 \mathrm{~b}$ \\
\hline H39, interval + lime sulfur if RIMpro $>200$ & $11+10$ & $16.4 \mathrm{c}$ & $13.5 \mathrm{c}$ \\
\hline Lime sulfur if RIMpro $>200$ & 10 & $18.5 \mathrm{c}$ & $14.3 \mathrm{c}$ \\
\hline
\end{tabular}

w Orchards trials in Eperjeske, Hungary, on Idared.

$x$ Values of the same assessment date followed by a common letter do not differ significantly (least significant difference test, $\alpha=5 \%$ ).

y Treatments applied during the summer season from 8 June to 7 September 2012; assessment of scab incidence on 3 October 2012.

z Treatments applied during the primary season from 26 March to 4 June 2013; assessment of scab incidence on 21 June 2013.

Table 6. Effects of multiple treatments of Cladosporium cladosporioides H39 and dithianon on apple scab disease incidence (DI) and severity (DS) on leaves and fruit ${ }^{\mathrm{u}}$

\begin{tabular}{|c|c|c|c|c|c|c|c|c|c|c|c|}
\hline \multirow[b]{3}{*}{ Treatment } & \multirow[b]{3}{*}{$N^{\mathrm{v}}$} & \multicolumn{4}{|c|}{ Scab on leaves } & \multicolumn{6}{|c|}{ Scab on fruit } \\
\hline & & \multicolumn{2}{|c|}{25 June } & \multicolumn{2}{|c|}{17 October } & \multicolumn{2}{|c|}{26 July } & \multicolumn{2}{|c|}{10 September } & \multicolumn{2}{|c|}{12 September } \\
\hline & & DI & $\overline{\text { DS }}$ & DI & $\overline{\text { DS }}$ & DI & $\overline{\text { DS }}$ & DI & DS & DI & DS \\
\hline \multicolumn{12}{|l|}{ Trial on Cortland ${ }^{\mathrm{w}}$} \\
\hline Untreated control & $\ldots$ & $62.3 \mathrm{c}$ & $1.4 \mathrm{~b}$ & $100.0 \mathrm{~d}$ & $4.9 \mathrm{c}$ & $65.6 \mathrm{c}$ & $1.6 \mathrm{c}$ & $\ldots$ & $\ldots$ & $83.8 \mathrm{c}$ & $4.7 \mathrm{c}$ \\
\hline Dithianon $^{\mathrm{x}}$ & 8 & $9.4 \mathrm{a}$ & $0.1 \mathrm{a}$ & $45.6 \mathrm{~b}$ & $1.2 \mathrm{a}$ & $7.9 \mathrm{a}$ & $0.1 \mathrm{a}$ & $\ldots$ & $\ldots$ & $5.0 \mathrm{a}$ & $0.1 \mathrm{a}$ \\
\hline H39 interval & 14 & $33.3 \mathrm{~b}$ & $0.6 \mathrm{a}$ & $58.3 \mathrm{c}$ & $2.3 \mathrm{~b}$ & $33.0 \mathrm{~b}$ & $0.6 \mathrm{~b}$ & $\ldots$ & $\ldots$ & $49.5 \mathrm{~b}$ & $1.2 \mathrm{~b}$ \\
\hline H39 interval + dithianon ${ }^{\mathrm{x}}$ & $14+8$ & $7.8 \mathrm{a}$ & $0.1 \mathrm{a}$ & $31.1 \mathrm{a}$ & $0.7 \mathrm{a}$ & $5.9 \mathrm{a}$ & $0.1 \mathrm{a}$ & $\ldots$ & $\ldots$ & $15.3 \mathrm{a}$ & $0.3 \mathrm{a}$ \\
\hline \multicolumn{12}{|l|}{ Trial on McIntosh ${ }^{y}$} \\
\hline Untreated control & $\ldots$ & $\ldots$ & $\ldots$ & $37.5 \mathrm{~b}$ & $0.9 \mathrm{~b}$ & $\ldots$ & $\ldots$ & $26.0 \mathrm{~d}$ & $0.5 \mathrm{c}$ & $\ldots$ & $\ldots$ \\
\hline H39, after infection ${ }^{z}$ & 4 & $\ldots$ & $\ldots$ & $37.6 \mathrm{~b}$ & $1.0 \mathrm{~b}$ & $\ldots$ & $\ldots$ & $12.5 \mathrm{c}$ & $0.2 \mathrm{~b}$ & $\ldots$ & $\ldots$ \\
\hline Dithianon after infection ${ }^{\mathrm{z}}$ & 4 & $\ldots$ & $\ldots$ & $15.8 \mathrm{a}$ & $0.3 \mathrm{a}$ & $\ldots$ & $\ldots$ & $5.5 \mathrm{ab}$ & $0.1 \mathrm{a}$ & $\ldots$ & $\ldots$ \\
\hline Dithianon after infection $+\mathrm{H} 39$ interval $^{\mathrm{z}}$ & $4+9$ & $\ldots$ & $\ldots$ & $12.9 \mathrm{a}$ & $0.2 \mathrm{a}$ & $\ldots$ & $\ldots$ & $4.0 \mathrm{a}$ & $0.1 \mathrm{a}$ & $\ldots$ & $\ldots$ \\
\hline H39 interval & 9 & $\ldots$ & $\ldots$ & $20.6 \mathrm{a}$ & $0.4 \mathrm{a}$ & $\ldots$ & $\ldots$ & $8.5 \mathrm{~b}$ & $0.1 \mathrm{ab}$ & $\ldots$ & $\ldots$ \\
\hline
\end{tabular}

u Orchard trials in Dabrowice in 2013. Values of the same assessment date followed by a common letter do not differ significantly (least significant difference test, $\alpha=5 \%$ ).

$\checkmark$ Number of applications

w Treatments applied during the whole growing season from 29 April to 22 August on Cortland.

x If RIMpro > 200.

y Treatments applied during the summer season from 14 June to 23 August on McIntosh.

${ }^{\mathrm{z}}$ One day after RIMpro indicated infection. 
apple scab. A first attempt to develop a rationale for an improved timing of spray applications focusing on scab development rather than fixed intervals as calendar sprays was made by spraying 1 day after predicted infection events. This strategy was slightly less effective than calendar sprays. Also, in the trial in 2013 at the same location during the primary season, calendar sprays of $C$. cladosporioides H39 were as effective as a copper-based spray schedule (Table 5, trial 2013). Sprays after predicted ascospore infections significantly reduced scab incidence on leaves and fruit $(P<0.001)$. However, such a schedule was less effective than calendar sprays. Combining weekly calendar sprays of $C$. cladosporioides H39 with lime sulfur application when high infection risks were predicted (RIMpro > 200) gave the best control effects but the additional effect of antagonist applications compared with the lime sulfur treatments without antagonist was not significant.

A scab epidemic throughout the whole season trial in Dabrowice on 'Cortland' apple was severe, with a leaf scab incidence of $>60 \%$ already in July and $100 \%$ in October (Table 6, Cortland). Under these conditions, the weekly calendar application of C. cladosporioides $\mathrm{H} 39$ significantly reduced scab incidence and severity on leaves and fruit by approximately $50 \%(P<0.001)$. Treatments with dithianon were significantly more effective. A significant additional effect of weekly sprays of C. cladosporioides $\mathrm{H} 39$ in combination with dithianon sprays (if RIMpro > 200) could be found for leaf scab incidence at the end of the season in October. In the trial at the same location carried out during the

Table 7. Effects of multiple treatments of Cladosporium cladosporioides $\mathrm{H} 39$, dithianon, or dodine during the primary season on apple scab incidence on leaves ${ }^{\mathrm{x}}$

\begin{tabular}{|c|c|c|c|c|}
\hline \multirow[b]{2}{*}{ Treatment } & \multirow[b]{2}{*}{ Number of applications } & \multicolumn{3}{|c|}{$\begin{array}{c}\text { Scab incidence }(\%) \text { on } \\
\text { leaves }\end{array}$} \\
\hline & & 10 May & 23 May & 5 June \\
\hline \multicolumn{5}{|l|}{ Trial $2012^{\mathrm{y}}$} \\
\hline Untreated control & $\ldots$ & $19.5 \mathrm{a}$ & $58.1 \mathrm{a}$ & $\ldots$ \\
\hline Dithianon & 8 & $2.5 \mathrm{c}$ & $15.9 \mathrm{c}$ & $\ldots$ \\
\hline $\mathrm{H} 39,2 \times 10^{6} / \mathrm{ml}$ & 8 & $11.0 \mathrm{~b}$ & $45.5 \mathrm{~b}$ & $\ldots$ \\
\hline \multicolumn{5}{|l|}{ Trial $2013^{z}$} \\
\hline Untreated control & $\ldots$ & $\ldots$ & $16.6 \mathrm{a}$ & $49.2 \mathrm{a}$ \\
\hline Dodine & 9 & $\ldots$ & $0.0 \mathrm{c}$ & $1.5 \mathrm{c}$ \\
\hline $\mathrm{H} 39,2 \times 10^{6} / \mathrm{ml}$ & 9 & $\ldots$ & $4.8 \mathrm{~b}$ & $22.3 \mathrm{~b}$ \\
\hline $\mathrm{H} 39,6 \times 10^{6} / \mathrm{ml}$ & 9 & $\ldots$ & $3.9 \mathrm{~b}$ & $19.6 \mathrm{~b}$ \\
\hline \multicolumn{5}{|c|}{$\begin{array}{l}\text { x Orchard trials in Bavendorf, Germany, on Golden Delicious. Values of the } \\
\text { same assessment date followed by a common letter do not differ significantly } \\
\text { (least significant difference test, } \alpha=5 \% \text { ). }\end{array}$} \\
\hline
\end{tabular}

summer epidemic on 'McIntosh', four applications of C. cladosporioides $\mathrm{H} 39$, applied after prediction of $V$. inaequalis infections by RIMpro, did not control leaf scab but significantly reduced fruit scab incidence and severity (Table 6, McIntosh) $(P<0.001)$. Nine weekly applications of the antagonist were more effective on fruit and also reduced leaf scab. Applications of dithianon after infection events tended to be more effective than C. cladosporioides $\mathrm{H} 39$ but differences were never significant. Combination of the dithianon spray schedule with the weekly spray schedule with C. cladosporioides $\mathrm{H} 39$ resulted in the highest control levels on both leaves and fruit.

In the trials in Bavendorf during the primary season, C. cladosporioides H39 was applied before predicted infection events in 2012 and after predicted infection events in 2013. Both spray schedules resulted in significant reductions of leaf scab (Table 7) $(P=0.002$ for assessment on 10 May 2012 and $P<0.001$ for other assessment dates). However, with 71 and 55\% (two assessment dates), efficacy (calculated as relative reduction with untreated control $=0 \%$ ) was higher when the antagonist was sprayed after infection events than when sprays were applied before infection events when values were 44 and $22 \%$ (two assessment dates). Application of a threefold dose rate of the antagonist did not enhance the effect. In the trial in Bavendorf during the summer epidemic 2012, scab incidence on leaves and fruit was low (Table 8, trial 2012). Weekly applications of $C$. cladosporioides $\mathrm{H} 39$ and of dithianon significantly reduced fruit scab $(P=0.032)$. A high fruit scab incidence of almost $71 \%$ was observed in the untreated control at the end of the 2013 season (Table 8, trial 2013). C. cladosporioides H39 applications after infection events significantly reduced scab incidence $(P<0.001)$ by more than $90 \%$, not different from the effect of a dodine spray schedule.

No phytotoxicity symptoms were observed in plots treated with C. cladosporioides H39 in the eight orchard trials.

Trials with single applications in Randwijk. Three additional trials with different timing of single treatments of $C$. cladosporioides $\mathrm{H} 39$ before or after an expected infection by $V$. inaequalis were carried out in 2013. Trial 1 started after a period of 16 days without infection events. After treatments had been carried out before and after an infection event on 13 June, five more infection events were recorded before leaves were sampled after 20 days. Under these conditions, most sporulation of $V$. inaequalis was found on the youngest leaves (Fig. 4). Single applications of $C$. cladosporioides $\mathrm{H} 39$ tended to reduce the number of $V$. inaequalis conidia, especially when sprayed after the infection event. A significant reduction by $74 \%$ was found on the youngest leaves when C. cladosporioides H39 was sprayed on 15 June, 774 degree h after infection. Pooled samples of the three leaf ages showed significantly reduced sporulation when C. cladosporioides $\mathrm{H} 39$ had been sprayed on 15 June (774 degree $h$ after infection) or on 21 June (3,070 degree $h$ after infection). Treatments of trial 2 were carried out before and after an infection

Table 8. Effects of multiple treatments of Cladosporium cladosporioides $\mathrm{H} 39$ and of dithianon or dodine during the summer season on apple scab incidence on leaves and fruit $^{\mathrm{w}}$

\begin{tabular}{|c|c|c|c|c|c|c|c|}
\hline \multirow[b]{2}{*}{ Treatment } & \multirow[b]{2}{*}{$N^{\mathrm{x}}$} & \multicolumn{3}{|c|}{ Scab incidence $(\%)$ on leaves } & \multicolumn{3}{|c|}{ Scab incidence $(\%)$ on fruit } \\
\hline & & 6 June & 11 July & 18 July & 8 August & 21 September & 26 September \\
\hline \multicolumn{8}{|l|}{ Trial 2012y } \\
\hline Untreated control & $\ldots$ & $0.1 \mathrm{n} . \mathrm{s}$. & 1.6 n.s. & $\ldots$ & 1.5 n.s. & $5.5 \mathrm{a}$ & $\ldots$ \\
\hline Dithianon & 15 & 0.4 & 1.8 & $\ldots$ & 0.7 & $0.8 \mathrm{~b}$ & $\ldots$ \\
\hline $\mathrm{H} 39,2 \times 10^{6} / \mathrm{ml}$ & 15 & 0.3 & 1.9 & $\ldots$ & 0.3 & $1.3 \mathrm{~b}$ & $\ldots$ \\
\hline \multicolumn{8}{|l|}{ Trial $2013^{z}$} \\
\hline Untreated control & $\ldots$ & 0.0 n.s. & $\ldots$ & $17.6 \mathrm{a}$ & $\ldots$ & $\ldots$ & $70.8 \mathrm{a}$ \\
\hline Dodine & 10 & 0.3 & $\ldots$ & $1.1 \mathrm{~b}$ & $\ldots$ & $\ldots$ & $0.6 \mathrm{~b}$ \\
\hline $\mathrm{H} 39,2 \times 10^{6} / \mathrm{ml}$ & 10 & 0.3 & $\ldots$ & $0.7 \mathrm{~b}$ & $\ldots$ & $\ldots$ & $3.5 \mathrm{~b}$ \\
\hline $\mathrm{H} 39,6 \times 10^{6} / \mathrm{ml}$ & 10 & 0.0 & $\ldots$ & $0.3 \mathrm{~b}$ & $\ldots$ & $\ldots$ & $4.6 \mathrm{~b}$ \\
\hline
\end{tabular}

${ }^{\mathrm{w}}$ Orchard trials in Bavendorf, Germany, on Golden Delicious. Values of the same assessment date followed by a common letter do not differ significantly (least significant difference test, $\alpha=5 \%$ ); n.s. = no significant differences.

$\mathrm{x}$ Number of applications.

y Treatments applied before predicted infection periods from 11 June to 18 September 2012.

${ }^{z}$ Treatments applied after infection periods from 11 June to 17 September 2013. 
event on 19 June, only 5 days after an earlier infection event. There were four more infection events before sampling. Treatments of trial 3 were carried out before and after an infection event on 3 July but earlier infection events had been recorded 4 and 9 days before the trial started. There were two more infection events before sampling. Under the conditions of trials 2 and 3, more conidia of $V$. inaequalis were found on the elder leaves (indicating infections before the start of the experiment) and no treatment effects by single applications of C. cladosporioides $\mathrm{H} 39$ were found (data not shown).

Effect of crop protection products on $C$. cladosporioides $\mathbf{H 3 9}$. The various fungicides and insecticides commonly used in integrated pest management schedules in commercial orchards had a different effect on in vitro conidial germination and mycelial growth of C. cladosporioides H39 (Figs. 1-3). Delan (dithianon) and Stroby (kresoxim-methyl), commonly used for scab control during the primary season; Nimrod (bupirimate), used for powdery mildew control; and Folicur (tebuconazole) used for scab control and the control of various other fruit diseases during the summer season, did not completely inhibit $C$. cladosporioides H39 even at the highest dose (Fig. 1), whereas several other fungicide products such as Score (difenoconazole), Topaz (penconazole), and Bellis (pyraclostrobin combined with boscalid) inhibited the antagonist even at lower concentrations. Insecticides and a chemical thinner were not strong inhibitors (Fig. 2). Among the crop protection products commonly used in organic farming, insecticides and sulfur only had a weak effect on C. cladosporioides $\mathrm{H} 39$ whereas other fungicides strongly inhibited the antagonist (Fig. 3).

\section{Discussion}

Eight trials were conducted under a range of environmental conditions during 2 years in Eperjeske and Dabrowice, locations with a continental climate, usually moderately conducive to apple scab; and in Bavendorf, a location with conditions highly conducive to apple scab due to the local climate. Four different cultivars were used: 'Idared', moderately susceptible to scab; 'Golden Delicious', moderately to highly susceptible to scab; and Cortland and McIntosh, highly susceptible to scab. The overall results of the eight field trials consistently showed-for the first time-that stand-alone applications of the antagonist $C$. cladosporioides $\mathrm{H} 39$ can reduce apple scab in leaves and fruit. This was demonstrated in an organic growing system as well as in conventional orchards by spray schedules applied

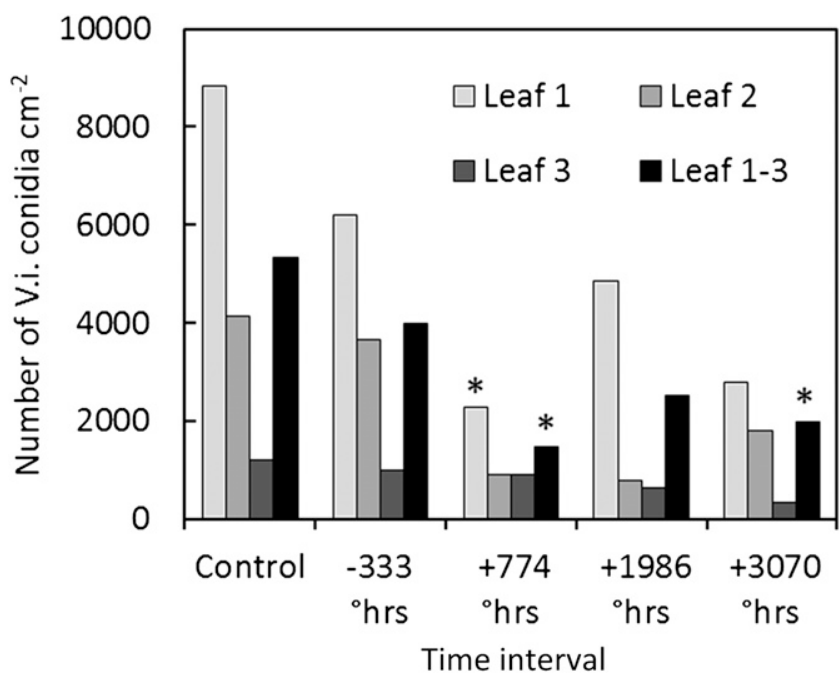

Fig. 4. Effect of the time interval (expressed as degree hours) between a predicted infection event by Venturia inaequalis and a spray application of conidia of Cladosporium cladosporioides $\mathrm{H} 39$ on the number of $\mathrm{V}$. inaequalis conidia produced on apple leaves of different age. Leaf 1 was the youngest leaf, not yet unfolded at the beginning of the trial, and leaves 2 and 3 were the next youngest leaves. Significantly lower numbers of conidia on treated leaves compared with the corresponding control leaves are indicated by asterisks (one-sided least significant difference test of $\log _{10}$-transformed values, $\alpha=5 \%$ ). Backtransformed means of six replicates, each consisting of five leaves. during the primary or the summer season. In both systems, disease level reductions were the same as those reached with common fungicide schedules in some trials.

These results are a first step toward the integrated use of the antagonist C. cladosporioides H39 in scab control strategies. Optimum spray schedules in fruit production have to combine different crop protection products for control of apples scab, other diseases, and pests. Schedules will always depend on the specific situation in the orchard. Important factors are local and seasonal climate, cultivar, specific orchard conditions, including its scab history, but also grower's preferences and the availability of fungicides, the reduced susceptibility of the local $V$. inaequalis populations to certain fungicides, and market demands for maximum levels of residues on harvested fruit. In this complex situation, knowledge is needed for the optimum positioning of $C$. cladosporioides $\mathrm{H} 39$ in crop protection schedules. The information gained in our study leads to the conclusion that the antagonist can potentially replace fungicide treatments in spray schedules used for scab control. Furthermore, in vitro studies indicated that the antagonist may be compatible with certain crop protection products, so that combined or alternating use can be an option.

Another finding is that the antagonist is also effective if applied one or even several days after infection events (equivalent to approximately 300 to 2,000 degree $\mathrm{h}$ under field conditions). This has been found in several field trials and has been confirmed by the trial conducted in Randwijk with single-spray applications at different intervals before or after a predicted infection event. In this trial, the antagonist significantly reduced $V$. inaequalis sporulation when sprayed 774 or 3,070 degree $\mathrm{h}$ after an infection event and tended to reduce sporulation also when sprayed after 1,986 degree h $(P>$ 0.05 due to variation between replicates). The finding is also in line with the screening procedure used during the selection of $C$. cladosporioides $\mathrm{H} 39$ in seedling tests where candidate antagonists were sprayed 5 to 6 days after inoculation with $V$. inaequalis (21). During this period, $V$. inaequalis is producing stromata under the cuticle, followed by the formation of conidiophores breaking through the cuticle after approximately 2,800 degree h (W. M. L. Molhoek et al., unpublished). Biological control effects of applications after infection are quite uncommon. In many cases, head starts of antagonists are a prerequisite (e.g., in case their mode of action is based on competition [19] or induced resistance [29]). V. inaequalis colonizes its host in a very specific way, with its characteristic subcuticular growth on the epidermis cells (4). Several chemicals have been successfully applied to induce resistance in apple against $V$. inaequalis (27) under field conditions. Ortega et al. (26) used methyl 2,6-dichlorisonicotinate to induce resistance in apple leaves against $V$. inaequalis and investigated the effects of induced resistance on the infection cycle of $V$. inaequalis. There was no effect on germination and appressorium formation on the apple leaf. After penetration of the cuticle, however, stromata were formed by the pathogen later and only $10 \%$ of such stromata developed runner hyphae. Only a few secondary stromata were produced, so that the colonization of leaves by $V$. inaequalis as well as the formation of conidia was strongly reduced. Thus, induced resistance resulting in a reduced or even completely inhibited sporulation may delay or even stop scab epidemics. Microscopic observations showed no signs of visible harm to the pathogen developing between cuticle and epidermis cells. Hypersensitive reactions by the host were not found (26). Ortega et al. (26) hypothesized that the postpenetration development of $V$. inaequalis is reduced as result of a reduced nutrient supply in the leaves. In susceptible apple tissue, melanoproteins of $V$. inaequalis increase the permeability of host cell membranes, resulting in an increasing nutrient supply by the host (16). C. cladosporioides $\mathrm{H} 39$ may also interfere with the pathogen mainly during this specific developmental stage. Studies on the specific mode of action of $C$. cladosporioides $\mathrm{H} 39$ as well as population dynamics of the antagonist after field applications are ongoing (J. Köhl et al., unpublished). Better understanding of the biology of the antagonist will help to further exploit its use in apple scab control. 


\section{Acknowledgments}

Parts of this study are results of the EU projects PURE 265865 and CO-FREE 289497, which were co-funded by the European Commission. We also acknowledge the financial support by the Dutch Ministry of Economic Affairs (BO25.10-005-001-PRI) (to J. Köhl), the Hungarian Scientific Research Fund (K108333), and the European Commission and the State of Hungary (European Social Fund, TÁMOP-4.2.4.A/2-11/1-2012-0001 'National Excellence Program', project number: A2-SZJTOK-13-0061) (to I. J. Holb).

\section{Literature Cited}

1. Andrews, J. H., Berbee, F. M., and Nordheim, E. V. 1983. Microbial antagonism to the imperfect stage of the apple scab pathogen, Venturia inaequalis. Phytopathology 73:228-234.

2. Beresford, R. M., Wright, P. J., Wood, P. N., Park, N. M., Larsen, N. J., and Fisher, B. M. 2013. Resistance of Venturia inaequalis to demethylation inhibitor and dodine fungicides in four New Zealand apple-growing regions. N. Z. Plant Prot. 66:274-283.

3. Boudreau, M. A., and Andrews, J. H. 1987. Factors influencing antagonism of Chaetomium globosum to Venturia inaequalis: A case study in failed biocontrol. Phytopathology 77:1470-1475.

4. Bowen, J. K., Mesarich, C. H., Bus, V. G. M., Beresford, R. M., Plummer, K. M., and Templeton, M. D. 2011. Venturia inaequalis: The causal agent of apple scab. Mol. Plant Pathol. 12:105-122.

5. Burr, T. J., Matteson, M. C., Smith, C. A., Corral-Garcia, M. R., and Huang, T.-C. 1996. Effectiveness of bacteria and yeasts from apple orchards as biological control agents of apple scab. Biol. Control 6:151-157.

6. Carisse, O. 2000. 50 years of research on biological control. Integrated control of pome fruit diseases. IOBC WPRS Bull. 23:5-10.

7. Carisse, O., and Dewdney, M. 2002. A review of non-fungicidal approaches for the control of apple scab. Phytoprotection 83:1-29.

8. Carisse, O., Philion, V., Rolland, D., and Bernier, J. 2000. Effect of fall application of fungal antagonists on spring ascospore production of the apple scab pathogen, Venturia inaequalis. Phytopathology 90:31-37.

9. European Union. 2009. Directive 2009/128/EC of the European Parliament and of the Council of 21 October 2009 establishing a framework for community action to achieve the sustainable use of pesticide. Online publication. Off. J. Eur. Union. L 309/71-86. http://faolex.fao.org/docs/pdf/ eur113943.pdf

10. Fiaccadori, R., Cicognani, E., Alberoni, G., Collina, M., and Brunelli, A. 2011. Sensitivity to strobilurin fungicides of Italian Venturia inaequalis populations with different origin and scab control. Pest Manag. Sci. 67: 535-540.

11. Fiss, M., Barckhausen, O., Gherbawy, Y., Kollar, A., Hamamoto, M., and Auling, G. 2003. Characterization of epiphytic yeasts of apple as potential biocontrol agents against apple scab (Venturia inaequalis). $\mathrm{Z}$. Pflanzenkrankh. Pflanzenschutz 110:513-523.

12. Fiss, M., Kucheryava, N., Schönherr, J., Kollar, A., Arnold, G., and Auling, G. 2000. Isolation and characterization of epiphytic fungi from the phyllosphere of apple as potential biocontrol agents against apple scab (Venturia inaequalis). Z. Pflanzenkrankh. Pflanzenschutz 107:1-11.
13. Gomez, C., Brun, L., Chauffour, D., and Vallée, D. D. L. 2007. Effect of leaf litter management on scab development in an organic apple orchard. Agric. Ecosyst. Environ. 118:249-255.

14. Guérin, F., and Le Cam, B. 2004. Breakdown of the scab resistance gene $V f$ in apple leads to a founder effect in populations of the fungal pathogen Venturia inaequalis. Phytopathology 94:364-369.

15. Heye, C. C., and Andrews, J. H. 1983. Antagonism of Athelia bombacina and Chaetomium globosum to the apple scab pathogen Venturia inaequalis. Phytopathology 73:650-654.

16. Hignett, R. C., and Kirkham, D. S. 1967. The role of extracellular melanoproteins of Venturia inaequalis inhost susceptibility. J. Gen. Microbiol. 48:269-275.

17. Holb, I. J. 2006. Effect of six sanitation treatments on leaf litter density, ascospore production of Venturia inaequalis and scab incidence in integrated and organic apple orchards. Eur. J. Plant Pathol. 115:293-307.

18. Holb, I. J., Heijne, B., and Jeger, M. J. 2005. The widespread occurrence of overwintered conidial inoculum of Venturia inaequalis on shoots and buds in organic and integrated apple orchards across The Netherlands. Eur. J. Plant Pathol. 111:157-168.

19. Kessel, G. J. T., de Haas, B. H., van der Werf, W., and Köhl, J. 2002. Competitive substrate colonisation by Botrytis cinerea and Ulocladium atrum in relation to biological control of B. cinerea in cyclamen. Mycol. Res. 106:716-728.

20. Köhl, J. A. 2009. Novel micro-organisms controlling plant pathogens International Patent Application WO 2009/078710.

21. Köhl, J., Molhoek, W. M. L., Groenenboom-de Haas, B. H., and Goossen-van de Geijn, H. M. 2009. Selection and orchard testing of antagonists suppressing conidia production of the apple scab pathogen Venturia inaequalis. Eur. J. Plant Pathol. 123:401-414.

22. Li, B., and Xu, X. 2002. Infection and development of apple scab (Venturia inaequalis) on old leaves. J. Phytopathol. 150:687-691.

23. MacHardy, W. E. 1996. Apple Scab: Biology, Epidemiology, and Management. American Phytopathological Society, St. Paul, MN.

24. MacHardy, W. E., Gadoury, D. M., and Gessler, C. 2001. Parasitic and biological fitness of Venturia inaequalis: Relationship to disease management strategies. Plant Dis. 85:1036-1051.

25. Manktelow, D. W. L., Beresford, R. M., Batchelor, T. A., and Walker, J. T. S 1996. Use patterns and economics of fungicides for disease control in New Zealand apples. Acta Hortic. 422:187-192.

26. Ortega, F., Steiner, U., and Dehne, H.-W. 1998. Induced resistance to apple scab: Microscopic studies on the infection cycle of Venturia inaequalis (Cke.). Wint. J. Phytopathol. 146:399-405.

27. Percival, G. C., Noviss, K., and Haynes, I. 2009. Field evaluation of systemic inducing resistance chemicals at different growth stages for the control of apple (Venturia inaequalis) and pear (Venturia pirina) scab. Crop Prot. 28:629-633.

28. Sutton, D. K., MacHardy, W. E., and Lord, W. G. 2000. Effects of shredding or treating apple leaf litter with urea on ascospore dose of Venturia inaequalis and disease buildup. Plant Dis. 84:1319-1326.

29. Vallad, G. E., and Goodman, R. M. 2004. Systemic acquired resistance and induced systemic resistance in conventional agriculture. Crop Sci. 44: 1920-1934. 